DOI: http://doi.org/10.30651/must.v5i1.3660

\title{
PENGARUH KEMAMPUAN NUMBER SENSE TERHADAP HASIL BELAJAR MATEMATIKA SISWA DI SMP NEGERI 8 TARAKAN
}

\author{
Alfian Mucti ${ }^{1}$, Nurmala $\mathbf{R}^{2}$ \\ ${ }^{1,2}$ Universitas Borneo Tarakan \\ alfianmucti@gmail.com ${ }^{1}$,nurmala.r17@gmail.com²
}

Received 27 November 2019; revised 28 April 2020; accepted 27 May 2020.

\begin{abstract}
ABSTRAK
Tujuan dari penelitian ini untuk mengetahui pengaruh number sense terhadap hasil belajar matematika siswa di SMP Negeri 8 Tarakan sehingga guru dapat merencanakan pembelajaran dari karakteristik number sense yang mereka miliki. Populasi dalam penelitian ini adalah seluruh kelas VIII di SMP N 8 Tarakan sedangkan pengambilan sampel menggunakan teknik simple random sampling. Teknik yang digunakan dalam penelitian ini adalah analisis regresi linier sederhana dimana kemampuan number sense siswa sebagai $X$ dan hasil belajar matematika siswa sebagai $Y$. dari hasil penelitian diperoleh model persamaan linier regresi sederhana $\hat{Y}=4,003+0,22 X$ dimana jika kemampuan number sense siswa nol maka hasil belajar matematika siswa 4,003 sedangkan jika kemampuan number sense meningkat sebesar 1 satuan maka hasil belajar siswa akan naik sebesar 0,22 . Sedangkan dengan menggunakan $R$ square diperoleh nilai sebesar 0,163 artinya pengaruh number sense hanya sekitar $16,3 \%$ terhadap hasil belajar matematika, artinya salah satu hal yang mempengaruhi hasil belajar matematika siswa adalah kemampuan number sense.
\end{abstract}

Kata kunci: number sense, regresi, hasil belajar matematika.

\begin{abstract}
The purpose of this research, to know the influence of number sense on student mathematics learning results in SMP Negeri 8 Tarakan. The population in this study was all class VIII at SMP N 8 Tarakan while sampling using simple random sampling technique. The technique used in this research is a simple linear regression analysis where the student's number sense capabilities as $X$ and the outcome of learning mathematics as $Y$. From the results of the research obtained model linear equation of simple regression $\hat{Y}=4,003+0,22 X$ where the ability number sense of zero students then the results of learning Mathematics students 4.003 whereas if the ability number sense increased by 1 unit then the outcome of learning Students will go up by 0.22. While using the $R$ square obtained a value of 0.163 means the influence of number sense only about $16.3 \%$ on the outcome of mathematical learning..
\end{abstract}

Keywords: number sense, regression, results test of mathematical learning. 


\section{PENDAHULUAN}

Matematika memiliki beberapa arti, diantaranya adalah (Abdurrahman, 2009): (1) Sebagai ilmu pengatahuan yang terorganisir secara terstruktur dan sistematis, (2) Sebagai pengetahuan bilangan dan bentuk kalkulasi, (3) sebagai pengetahuan tentang penalaran secara logis, (4) sebagai pengetahuan dengan hasil yang pasti dan memiliki aturan yang ketat. Dari beberapa pengertian tersebut dapat disimpulkan bahwa matematika merupakan pengetahuan dengan bahasa simbolis yang memiliki fungsi praktis untuk menunjukkan hubungan kuantitatif di dalam kehidupan di dalam berfikir logis dan sistematis.

Di dalam proses pendidikan, belajar merupakan hal yang paling penting dan mendasar, sehingga tujuan pendidikan selalu berlandaskan pada proses belajar yang dilalui oleh peserta didik. Belajar merupakan perubahan tingkah laku dari seseorang (Sardiman, 2011). Pembelajaran tidak hanya menerima pembelajaran dari guru secara pasif namun harus memenuhi kriteria mental secara aktif. Untuk itu, diperlukan kreativitas dari guru untuk dapat memberikan dorongan serta tantangan kepada siswa untuk berfikir (Indriati \& Hartono, 2011).

Dari kedua definisi tersebut dapat diambil suatu kesimpulan bahwa belajar matematika adalah proses untuk memahami bahasa simbolis yang memiliki fungsi praktis untuk menunjukkan hubungan kuantitatif di dalam kehidupan di dalam berfikir logis dan sistematis yang dapat merubah tingkah laku seseorang di dalam kehidupan. Sedangkan untuk dapat belajar matematika diperlukan kemampuan dasar yaitu kemampuan number sense.

Number sense adalah kepekaan seseorang untuk memahami bilangan, operasi bilangan dan hubungan antar bilangan yang berfungsi memberikan solusi terhadap masalah secara signifikan yang tidak bergantung pada algoritma atau prosedur yang konvensional. Siswa yang mempunyai kemampuan number baik, mempunyai intuisi yang baik pula tentang bilangan, memahami hubungan antar bilangan serta sifat-sifat bilangan. Bilangan yang dikuasai siswa dengan baik tentu akan dapat memaksimalkan pengetahuannya tentang bilangan untuk bermacammacam bidang dan kondisi dalam kehidupan, sehingga kemampuan number sense menjadi penting untuk dikuasai oleh setiap siswa (Greeno, 1978). 
Selanjutnya menurut Pilmer (Saleh, 2009) mengatakan bahwa kemampuan number sense yang dimiliki oleh setiap siswa berbeda-beda. Ini dikarenakan number sense berkembang seiring dengan pengetahuan dan pengalaman yang dialami siswa yang diperoleh dari pendidikan baik informal maupun formal. Oleh sebab itu, para pendidik harus mengajarkan, menggali dan menerapkan pengetahuan siswa sehingga mereka bisa meningkatkan kemampuan number sensenya selama proses pembelajaran. terutama kemampuan number sense mereka dalam memecahkan masalah matematika. Pada dasarnya kemampuan number sense merupakan kemampuan yang bisa dilatih pada setiap anak. Dari hal tersebut, guru perlu mengidentifikasi kemampuan number sense siswa dalam kelas agar dapat memahami karakteristik belajar siswa dan membuat keputusan perencanaan dan pelaksanaan pembelajaran di kelas. Berdasarkan uraian tersebut, menjadi penting untuk dapat mengetahui pengaruh number sense terhadap kemampuan siswa. Dalam hal ini, kemampuan siswa dilihat dari hasil belajar matematika secara kognitif.

\section{METODE PENELITIAN}

Variabel yang digunakan dalam penelitian ini menggunakan dua variabel bebas dan satu variabel terikat.

1. Variabel bebas dalam penelitian ini adalah kemampuan number sense siswa $(X)$

2. Variabel dependent atau biasa disebut dengan variabel terikat adalah hasil belajar matematika $(Y)$ yang dilihat dari nilai ulangan harian siswa pada materi relasi dan fungsi.

Dalam penelitian ini paradigma penelitian yang digunakan terdapat pada Gambar 1.

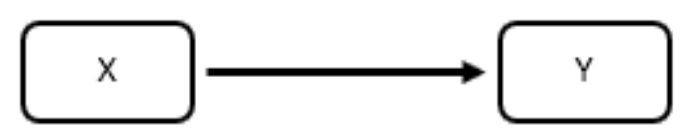

Gambar 1. Bagan Pengaruh $X$ terhadap $Y$

Keterangan:

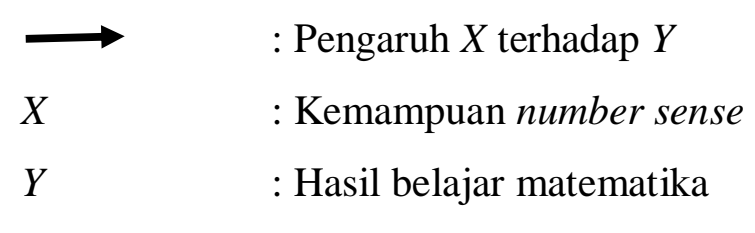


Adapun indikator yang digunakan dalam menilai kemampuan number sense siswa dapat dilihat dalam Tabel 1.

Tabel 1. Indikator Kriteria Penilaian Number Sense Siswa

\begin{tabular}{clc}
\hline No & \multicolumn{1}{c}{ Indikator } & Nomor Soal \\
\hline 1 & Number magnitude & 1,4 \\
2 & Number operation & 2,6 \\
3 & Computational Estimation & 3,7 \\
4 & Judging Reasonable of Result & 5,8 \\
\hline
\end{tabular}

Sebelum menentukan uji hipotesis, terlebih dahulu dilakukan pengujian persyaratan analisis yaitu uji normalitas dan uji linieritas (Sugiyono, 2015). Kriteria pengujian normalitas adalah jika data signifikansi berada di atas taraf kesalahan 5\% atau nilai signifikan > 0,05 maka seluruh data instrumen variabel berdistribusi secara normal. Sedangkan Uji linieritas dapat menggunakan kriteria pengujian jika pada grafik terlihat garis regresi yang mengarah ke kanan atas maka membuktikan adanya linearitas pada hubungan variabel bebas dan variabel terikat. Hipotesis untuk uji linearitas data adalah sebagai berikut:

H0 : Model regresi tidak linear

Ha : Model regresi linear

Jika nilai signifikansi $\leq 0,05$ maka $\mathrm{H} 0$ ditolak dapat disimpulkan bahwa data berpola linier, sedangkan jika nilai signifikansi > 0,05 maka H0 diterima, dapat disimpulkan bahwa data tidak berpola linier. Dan model regresi linear sederhana yang digunakan dapat dirumuskan sebagai berikut (Riduwan, 2012):

$$
\hat{Y}=\mathrm{a}+\mathrm{b} X
$$

Keterangan:

$\hat{Y} \quad$ : Hasil belajar

$X \quad$ : Kemampuan number sense

a : Konstanta harga $Y$ jika $X=0$

b : Koefisien regresi variabel $X$ (kemampuan number sense)

\section{HASIL PENELITIAN DAN PEMBAHASAN}

Setelah dilakukan pengumpulan data diperoleh hasil seperti ditunjukkan pada Tabel 2. Berdasarkan Tabel 2, diperoleh informasi bahwa rata-rata untuk number sense adalah 3,60 sedangkan untuk hasil belajar adalah 4,81. Kemudian 
untuk simpangan baku pada kemampuan number sense siswa diperoleh nilai 1,11 dan untuk hasil belajar adalah 0,625 .

Tabel 2. Nilai Number Sense dan Hasil Belajar Siswa

\begin{tabular}{clcccc}
\hline \multirow{2}{*}{ No } & Uraian & $\begin{array}{c}\text { Rata-Rata } \\
(0-10)\end{array}$ & $\begin{array}{c}\text { Simpangan } \\
\text { Baku }\end{array}$ & $\begin{array}{c}\text { Nilai } \\
\text { Tertinggi }\end{array}$ & $\begin{array}{c}\text { Nilai } \\
\text { Terendah }\end{array}$ \\
\hline 1 & Number sense & 3,60 & 1,11 & 7,5 & 2,5 \\
2 & Hasil belajar & 4,81 & 0,625 & 7 & 3,92 \\
\hline
\end{tabular}

Selanjutnya hasil uji normalitas dapat dilihat pada Tabel 3.

Tabel 3. Hasil Uji Normalitas

\begin{tabular}{lcccc}
\hline \multirow{2}{*}{ Uraian } & \multicolumn{2}{c}{ Kolmogorof-Smirnov } & \multirow{2}{*}{ Keputusan } & \multirow{2}{*}{ Kesimpulan } \\
\cline { 2 - 3 } & Statistik & Sig. & Uji & \\
\hline $\begin{array}{l}\text { Kemampuan number } \\
\text { sense }\end{array}$ & 0,116 & 0,200 & Terima H0 & Normal \\
Hasil belajar & 0,120 & 0,200 & Terima H0 & Normal \\
\hline
\end{tabular}

Berdasarkan hasil uji normalitas diketahui bahwa kedua data kemampuan number sense dan hasil belajar siswa lebih besar dari taraf signifikan yang diberikan yaitu 0,05 sehingga H0 diterima yang berarti bahwa data tersebut berdisribusi normal.

Kemudian dengan menggunakan untuk uji linieritas diperoleh nilai signifikansi sebesar 0,036 yang lebih besar dari 0,05 yang merupakan taraf signifikansi yang telah ditetapkan sehingga $\mathrm{H} 0$ ditolak yang berarti model regresi linier.

Berdasarkan data tersebut disimpulkan bahwa data memenuhi syarat untuk dibuat menjadi model regresi yang tertuang dalam persamaan berikut :

$$
\hat{Y}=4,003+0,224 X
$$

Keterangan:

$\hat{Y} \quad$ : Hasil belajar

$X \quad$ : Kemampuan number sense

a $: 4,003$

b : : 0,224

dimana jika kemampuan number sense siswa nol maka hasil belajar matematika siswa 4,003 sedangkan jika kemampuan number sense meningkat sebesar 1 satuan maka hasil belajar siswa akan naik sebesar 0,22. Hal ini menunjukkan bahwa semakin besar tingkat kemamuan number sense siswa maka berdampak positif terhadap hasil belajar matematika siswa. 
Ini sejalan dengan pendapat Mucti (2018) yang menyatakan bahwa untuk melakukan operasi matematika untuk menyelesaikan permasalahan yang berkaitan dengan matematika diperlukan keterampilan dasar dalam konsep matematika yang salah satu keterampilan konsep dasar dalam matematika adalah kemampuan number sense siswa.

Selanjutnya untuk mengetahui seberapa besar tingkat pengaruhnya kamampuan number sense terhadap hasil belajar siswa dapat dilihat dari $R$ square yang mempunyai nilai 0,163 yang memiliki arti bahwa kemampuan number sense siswa berpengaruh sebesar 16,3\% terhadap hasil belajar siswa khususnya di SMP Negeri 8 Tarakan.

\section{SIMPULAN}

Dari hasil penelitian yang dilakukan di SMP Negeri 8 Tarakan dipereroleh model regresi sederhana untuk kemampuan number sense siswa $(X)$ dan hasil belajar matematika $(Y)$ dengan bentuk $\hat{Y}=4,003+0,224 X$. Jika kemampuan number sense siswa nol maka hasil belajar matematika siswa 4,003, sedangkan jika kemampuan number sense meningkat sebesar 1 satuan maka hasil belajar siswa akan naik sebesar 0,22. Hal ini menunjukkan bahwa semakin besar tingkat kemampuan number sense siswa maka berdampak positif terhadap hasil belajar matematika siswa. Kemampuan number sense siswa berpengaruh sebesar 16,3\% terhadap hasil belajar siswa khususnya di SMP Negeri 8 Tarakan.

\section{DAFTAR PUSTAKA}

Abdurrahman, M. (2009). Pendidikan bagi anak berkesulitan belajar. Jakarta: PT Rineka Cipta.

A.M. Sardiman. (2011). Interaksi dan motivasi belajar mengajar. Jakarta: Rajawali Press.

Greeno, J.G. (1978). Natures of problem solving abilities. In W.K. Estes (ed) Handbook of learning and cognitive processes. Volume 5. Human Information Processing; New Jersey: Lawrence Erlbaum Associates, Publisher.

Indriati, I., \& Hartono, Y. (2011). Penerapan model pembelajaran cooperative tipe STAD dengan soal-soal pemecahan masalah pada mata pelajaran matematika di SMA negeri 6 Palembang. Jurnal Pendidikan Matematika. 5(2), 157-170. https://doi.org/10.22342/jpm.5.2.583.

Mucti, A., Izzatin, M., \& Nurmala, R. (2018) Pengembangan media "card 24" pada siswa SD kelas $\mathrm{V}$ dalam operasi hitung bilangan bulat. EDU-MAT: 
Pengaruh Kemampuan Number Sense terhadap Hasil Belajar Matematika Siswa di SMP Negeri 8

Tarakan

Jurnal Pendidikan Matematika, 6(1), 45-52. http://dx.doi.org/10.20527/edumat.v6i1.5119.

Riduwan. (2012). Metode \& teknik menyusun proposal penelitian. Bandung: Alfabeta.

Saleh, A. (2009). Number sense. Belajar matematika selezat coklat. Bandung: Trans Media Pustaka.

Sugiyono. (2015). Statistika untuk penelitian. Bandung: Alfabeta. 